\title{
PRISIÓN PROVISIONAL Y APLICACIÓN DE LA PRUEBA INDICIARIA COMO PROCEDIMIENTO PARA VALORAR LOS RIESGOS CAUTELARES. ${ }^{1}$
}

\author{
JOSÉ MARÍA ASENCIO MELLADO²
}

\section{Resumen.}

El objeto del presente trabajo es el de vincular la apreciación de los elementos o indicios que acreditan el periculum in mora al complejo que constituye la prueba indiciaria. Si la prisión provisional se adopta sobre la base de una presunción, que se construye sobre indicios que revelan los riesgos cautelares que la justifican, carece de justificación no aplicar al razonamiento judicial los requisitos de dicha prueba.

\section{Palabras clave:}

Prisión provisional. Medidas cautelares. Alarma social. Prueba indiciaria

\begin{abstract}
.
The purpose of this article is to link the assessment of the key evidentiary elements, which are demostrative o the existence of the so called periculum in mora into the complex meaning of circumstantial evidence. If prison on remand is adopted by the judge on the basis of a presumption, which builds on circunstancial evidence, that decision reveals the cautionary risks that

1 Este trabajo ha sido realizado en el marco de dos proyectos de investigación: DER2017-87516-P, financiado por el Ministerio de Economía, Industria y Competitividad y AICO/2017/146, financiado por la Consellería de Educación, Cultura y Deporte de la Generalitat Valenciana.

2 Catedrático de Derecho Procesal Universidad de Alicante Vocal Permanente de la Comisión General de Codificación del Reino de España.jm.asencio@ua.es.
\end{abstract}


justify it, so there is not arguments for not aplying the elements of that kind of evidence to judicial reasoning.

\section{Key words:}

Prison on remand. Cautionary measures. Social alarm. Circumstancial evidence.

\section{Introducción.}

El estudio de la prisión provisional se presenta como uno de los más complejos del Derecho procesal penal a pesar de su aparente sencillez. Esta complejidad deriva de razones muy diferentes, no todas ellas de la misma condición, pero que tienen en común coincidir con una aplicación que propicia la discrecionalidad judicial, en ocasiones más que eso y que lleva a que las medidas adoptadas dependan excesivamente de factores no estrictamente jurídicos.

Pudiera parecer que todo se ha escrito sobre esta medida, teóricamente cautelar y así denominada a pesar de todos los avatares por los que transcurre, que la degradan o convierten en cosa distinta con frecuencia y reiteración.

No es cierto, sin embargo, que esté todo dicho, pues precisamente esa susceptibilidad de la restricción a la libertad de verse dominada por influencias extrañas, ha estado en el origen de tratamientos muchas veces amplios, doctrinalmente impecables, pero muy apegados a las grandes declaraciones, necesarias, pero manifiestamente insuficientes para, al menos, lograr el objetivo propuesto: que la medida se considerara y adoptara conforme a su naturaleza, la cautelar y que los jueces la adoptaran previo análisis de sus presupuestos sin perder de vista esa condición.

$\mathrm{Si}$ bien es cierto que tales principios, presupuestos y caracteres han logrado penetrar en la práctica y que los tribunales se hacen eco de los mismos proclamándolos como criterios a los que se sujetan en su actividad, también lo es que el resultado de esa subordinación de los criterios legales a las normas y principios informadores, pero vinculantes constitucional y legalmente, no responde o no es el que debiera ser.

$\mathrm{Y}$ así, aunque declarados aquellos, su actuación concreta deviene contraria a lo proclamado, dándose lugar a una ampliación desmedida de la cautela, injustificada en su naturaleza, impropia de sus funciones 
consustanciales. Los dogmas o principios, se insiste de fuerza constitucional, quedan reducidos a formar parte de las resoluciones como meras ilustraciones teóricas sin aplicación real, deviniendo la prisión provisional en una suerte de medida anticipativa de la pena, que cumple sus funciones con carácter anterior y que atiende a fines muy alejados de los propios de la prisión provisional. Un instrumento de política criminal, de satisfacción de la "alarma social", ${ }^{3}$ de evitación de la reiteración delictiva y de excusa al Estado del cumplimiento de sus fines más básicos.

Hemos abandonado el tratamiento de los mecanismos a los cuales han de responder el análisis y la aplicación de los presupuestos de la medida, el fumus boni iuris y el periculum in mora, llenando páginas y libros de reflexiones ciertas, pero tan amplias, como subjetivas y particulares. Reflexiones obligadas e imprescindibles, pues toda valoración de riesgos e imputaciones ha de ser particularizada, pero tan genéricas, que no se han sometido a reglas jurídicas objetivas que aseguren cierta certeza jurídica y eviten la discrecionalidad más absoluta e insegura.

Y, de este modo, la inclusión en las leyes de criterios abiertos para que los tribunales valoren en cada caso los riesgos, se ha visto desarrollada por resoluciones que, pretendiendo que las valoraciones se adapten al caso y acrediten los peligros legalmente establecidos, no se sujetan a procedimiento alguno a los efectos de su análisis, valoración de suficiencia, racionalidad y resultado adecuado al fin. En definitiva, ha faltado una cierta y necesaria objetivación del mecanismo valorativo de los indicios, que son en realidad los criterios legales, en el marco de algo más que resoluciones genéricas que han consagrado la discrecionalidad sin sujeción a reglas procedimentales previas y comunes.

3 No se puede perder de vista que, frente al fin de evitar la reiteración delictiva, no cautelar, sino preventivo, la satisfacción de la llamada "alarma social" tiene naturaleza retributiva o vindicativa, que anticipa la pena no ya solo materialmente, sino incluso a los efectos de cumplir, de modo inmediato, los fines de la propia pena privativa de libertad. Vide ASENCIO MELLADO, JM.: La prisión provisional. Civitas, Madrid, 1987. Págs. 40 y 125 y ss. Se han mostrado partidarios, no obstante, de esta función autores, tales como MATTES, H.: "La prisión preventiva en España”. En: Anuario de Derecho Penal y Ciencias Penales, fascículo 2, Madrid, 1975. Pág. 20. CALVO SÁNCHEZ, C: "De nuevo sobre la prisión provisional. Análisis de la Ley Orgánica 10/1984, de 26 de diciembre”. En: Revista La Ley, 22 de marzo de 1985. En contra, cabe destacar a ORTELLS RAMOS, M: "Para una sistematización de las medidas cautelares”. En: RGLJ., Mayo, 1978. Págs. 457-458. Una fuerte crítica a esta función no cautelar realiza DEL RÍO LABARTHE, G: Las medidas cautelares personales del proceso penal peruano. Tesis Doctoral. Universidad de Alicante. 2009. Págs. 70 y ss. 
El abandono de la ley y un cierto desprecio por el procedimiento, rémora que cede ante la actividad intelectual del Juez, ha dado entrada en el proceso a una inseguridad que solo se remedia por los tribunales superiores mediante análisis a su vez de racionalidad y proporcionalidad que, aunque quieran objetivarse, contienen buena parte de dosis de subjetividad y abren la puerta a intereses no siempre compatibles con la naturaleza de las instituciones procesales.

Los indicios son un elemento de la prueba indiciaria, legalmente regulada y jurisprudencialmente interpretada y, como tales, habrían de ser aplicados en el ámbito de la prisión provisional, siendo la valoración un elemento de la actividad judicial, posterior y adecuado solo a su ámbito de aplicación concreta. Nunca el aspecto valorativo puede eludir la ley y el procedimiento, ni sustituirlo, sino complementarlo allí donde tiene su lugar propio. Un derecho procesal en el que el procedimiento es desterrado en favor de la apreciación judicial, por muy precisa que ésta sea, pierde su carácter de norma de derecho público, imperativa e indisponible en favor de la discrecionalidad. Se atribuye al Juez un papel que no es el propio de un sistema en el que es, fundamentalmente, aplicador de la ley, a la que está plenamente sometido. Cuando su función subjetiva se exacerba, se convierte en creador de derecho en el marco de un sistema positivista, generándose una crisis permanente de este mismo sistema.

Los avances en el terreno del Derecho procesal han venido, en los últimos años, de la mano de la consagración de normas objetivas, incrementadas en su eficacia por requisitos valorativos que, a su vez, se sujetaban a aquellas, que en todo caso eran preferentes. Se trataba de huir de la libérrima valoración de la prueba cuyo remedio no es solo el de la motivación, sino esencialmente el de las normas que disciplinan la actividad probatoria. $\mathrm{O}$, lo que es lo mismo, la ley sirvió, en materia probatoria, para limitar prescripciones que servían para prescindir del derecho a la presunción de inocencia y que el deber de motivación, posterior a esa fase histórica, no remedió por completo. Fue la ley y la delimitación de lo valorable como prueba, la que ciñó la actividad judicial valorativa a unos márgenes más o menos precisos. Porque, no se olvide, la libre valoración de la prueba, ilimitada, era propia de la institución del Jurado, no de los jueces técnicos, cuya sumisión a la ley y deber de motivación es compatible con exigencias legales que ciñan sus facultades a límites necesarios. ${ }^{4}$ Más aún, es obligada.

4 ASENCIO MELLADO, JM: Prueba prohibida y prueba preconstituida. S.A. Trivium, Madrid 1989. Págs. 33 y ss. 
La presunción de inocencia y su desarrollo no florecieron consagrando solo la motivación, sino que fueron fruto de una actividad legal y jurisprudencial que acotó la prueba, sus caracteres y sus condiciones, estableciendo incluso normas objetivas de valoración, como, por ejemplo, la obligada corroboración de las declaraciones de los coimputados.

De ahí que en materia de prisión provisional surja la inevitable consecuencia de establecer y determinar el mecanismo legal, procedimental, al que ha de sujetarse la valoración de los indicios legalmente establecidos, superando la mera referencia a motivaciones que, visto está, van degenerando en retórica y alteración paralela de la naturaleza cautelar de la prisión provisional. Que haya límites a la actividad valorativa en la sentencia, pero que éstos no se exijan cuando de aplicar la prisión provisional se trata, cuando es materialmente una anticipación de la pena y se tiene que fundamentar en un análisis acerca del presumible éxito de la misma pretensión penal, carece de justificación y responde o puede responder a razones que no es fácil entender y aceptar.

Este es el fin de este breve trabajo, el de referir prisión provisional y prueba indiciaria como mecanismo que cumpla esa finalidad ineludible y cuya ausencia está en la base de un futuro incierto que presenta sus credenciales cada vez con más entidad en esta sociedad tan inclinada al regreso al inquisitivo.

\section{La motivación de las resoluciones que acuerdan la prisión provisional. Correctivos necesarios.}

En un sistema en el que la prisión provisional no es automática, sino consecuencia de la apreciación en cada caso concreto de los riesgos que definen la medida y la ley consagra, la motivación de las decisiones que la adoptan constituye un momento culminante, pues, aunque se objetiven los criterios y se establezca un procedimiento de valoración, la abierta redacción de las normas que disciplinan la medida y los principios que la informan, se han de reflejar y expresar en toda resolución para acreditar que la misma es respetuosa con tan amplio abanico de prescripciones.

El deber de motivación, ante situaciones en las que debe apreciarse un peligro sobre la base de indicios y que ha de concluir en la afirmación de una presunción, no un hecho cierto y probado pasado, adquiere una relevancia especial, tanto que el TC español, en su sentencia 47/2000, de 17 de febrero, ha afirmado que este deber, en el marco de la restricción 
de la libertad de modo cautelar es distinto y mucho más estricto que el general derivado del derecho al proceso con todas las garantías. Y así, ha afirmado que su vulneración, sin más, implica la infracción del derecho a la libertad en tanto la ausencia de fundamentación expresa da lugar a que se pueda hablar de falta del supuesto habilitante de la restricción de la libertad cautelar.

La falta de motivación o la motivación insuficiente, se traduce en una nulidad de la resolución que, más allá de infringir el derecho a un proceso con todas las garantías, genera en estos casos la del derecho a la libertad.

"El análisis de dicha pretensión de amparo debe iniciarse recordando que este Tribunal ha establecido reiteradamente que el deber constitucional de motivación de las resoluciones judiciales limitativas de derechos fundamentales, expresando en ellas las circunstancias que justifican tal limitación es una exigencia formal del principio de proporcionalidad y persigue, como fin, hacer posible el debate y comprobación de la legalidad y racionalidad de la restricción acordada. Para ello, el órgano judicial, en la resolución que adopte, debe efectuar necesariamente el juicio de ponderación entre el derecho o derechos fundamentales afectados y los intereses que tal afectación trata de proteger. Hemos reiterado que si los órganos judiciales no motivan dichas resoluciones judiciales, infringen ya, por esta sola causa, los derechos fundamentales afectados (SSTC 26/1981, de 17 de julio; 27/1989, de 3 de febrero; 37/1989, de 15 de febrero; 8/1990, 18 de enero; 160/1991, de 18 de julio; 3/1992, de 13 de enero; 28/1993, de 25 de enero; 12/1994, de 17 de enero; 13/1994, de 17 de enero; 160/1994, de 23 de mayo; 50/1995, de 23 de febrero; 86/1995, de 6 de junio; 128/1995, de 26 de julio; 181/1995, de 11 de diciembre; 34/1996, de 11 de marzo; 37/1996, de 11 de marzo; 62/1996, de 16 de abril; 158/1996, de 15 de octubre, o 170/1996, de 29 de octubre). La restricción del ejercicio de un derecho fundamental necesita encontrar una causa especifica, y el hecho o la razón que la justifique debe explicitarse para hacer cognoscibles los motivos por los cuales el derecho se sacrificó. Por ello la motivación del acto limitativo, en el doble sentido de expresión del fundamento de Derecho en que se basa la decisión y del razonamiento seguido para llegar a la misma, es un requisito indispensable del acto de limitación del derecho (STC 52/1995, de 23 de febrero).

$\mathrm{Y}$, en este mismo sentido se ha expresado la Corte IDH, en sus sentencias dictadas en los casos NORÍN, YVON NEPTUNE, BARRETO LEYVA Vs, Venezuela de 20 de noviembre de 2009, J. Vs, Perú de 27 de noviembre 
de 2013 entre otros, en las que asegura que la falta de motivación supone considerar arbitraria la resolución judicial y con ello infractora de los arts. 7,3 y 8,2 de la CIDH.

Más tajante se muestra la Corte Suprema peruana, que en sus resoluciones 626-2013 y 631-2015 establece el deber de expresar de forma explícita la aplicación y respeto de los principios que informan la prisión provisional, siendo así que su falta, su remisión a fórmulas estereotipadas o insuficiente se considera una mera aplicación de lo que se denomina por la Resolución Administrativa 325-2011-P-PJ, peligrosismo procesal. Por peligrosismo procesal refiere San Martín ${ }^{5}$ los riesgos cautelares, si bien el mismo autor, en aquella resolución, determinó que el peligrosismo hacía referencia o, al menos así lo parecía, no a un presupuesto, sino a un exceso, a una presunción casi automática que considera peligros donde no hay otra cosa que referencias genéricas.

No es fácil, pues entender el significado de este término novedoso y, tal vez, el problema venga determinado por el uso de términos diferentes a los clásicamente propios del ámbito de que se trata. Es sabido que toda medida cautelar parte de dos presupuestos que la justifican: el fumus boni iuris $\mathrm{y}$ el periculum in mora. $\mathrm{Y}$ este último se denomina de este modo, como peligro derivado del retardo, pues esa es la razón de las medidas cautelares, cuya utilidad sería nula ante una Justicia inmediata. No es lo mismo, pues, habar de peligro derivado del retardo, que hacerlo de un genérico "peligro procesal", aunque el contenido sea el mismo.

El periculum in mora, a su vez, se concreta en diversos riesgos, cuya finalidad ha de ser estrictamente procesal, por instrumental, no preventivos o propios de la pena. Y todos ellos, aun respondiendo a un mismo presupuesto, aseguran el proceso -instrumentalidad-, en aquellos aspectos que deben serlo. Pero, cada fin es diferente, precisa de elementos valorativos no coincidentes, impone condiciones no asimilables entre ellas. Por tanto, hablar de un genérico peligro procesal y fundir en una misma relación los diferentes riesgos, enumerándolos, es poco adecuado para comprender el complejo normativo y teórico de la prisión provisional.

Peligros procesales hay muchos y con diferente fundamento y efectos, no solo los cautelares, de modo que referir como procesal el que es propio solo de las medidas de aquella naturaleza, no sirve para explicarlas en su

$5 \quad$ SAN MARTÍN CASTRO, C: Derecho Procesal Penal. Lecciones. INPECCPCENALES, Lima, 2015. Págs. 458 y ss. 
sentido propio. Peligro y procesal es el que justifica la ejecución provisional de las sentencias no firmes civiles, acto que no es de naturaleza cautelar. Peligro es el que justifica el aseguramiento de la prueba o su anticipación y tampoco son cautelares etc... Muchos peligros aparecen en el proceso, basados en un riesgo, pero sin poseer la cualidad de ser cautelares. Por eso, denominar con el nombre del género a una especie es incurrir en cierta indefinición que podría llevar a calificar como cautelares medidas que no lo son y viceversa. Ya ha sucedido y sucede en ocasiones, fruto de esa tendencia a denominar novedosamente lo que secularmente ya está identificado. Cuando se modifican los conceptos, aunque sea nominalmente, se corre el riesgo de abrir la puerta a errores de cierta importancia.

Ahora bien, como se ha indicado anteriormente y constituye el objeto central de esta reflexión, todo este conjunto de afirmaciones deja un espacio abierto que, en sí mismo, sin más consideraciones y sin la adecuación del razonamiento judicial a un concepto procesal, puede quedar reducido, como sucede en la práctica, a meras declaraciones teóricas, muy abiertas y que propician la discrecionalidad más absoluta. Valorar hechos de forma aislada, sin enmarcarlos en un complejo probatorio cuando tienen la cualidad de meros indicios, genera el efecto de atribuirles un valor del que carecen aquellos, de ser apreciados en ocasiones atribuyéndoles una entidad propia y única, aisladamente, sin que baste afirmar que es insuficiente la presencia de uno solo de los criterios legales cuando éstas alcanzan fuerza autónoma y dejan de funcionar como indicios en el marco de una prueba circunstancial.

Es decir, que ordenar la motivación de una decisión que se basa en indicios y presunciones sin reglas valorativas objetivas, legalmente establecidas y sin elementos determinados que sirvan para ajustar el comportamiento, deja un espacio tan amplio a la discrecionalidad que suele concluir en la más absoluta y libérrima apreciación, hecho éste que se opone a la seguridad jurídica que debe regir cuando se trata de limitación de derechos.

Un indicio debe ser calificado como tal y quedar sujeto a las condiciones propias de todo elemento de ese carácter, so pena de, al alterar su naturaleza, hacerlo funcionar como algo distinto. De ahí tal vez deriva la jurisprudencia casuística, pero tan insuficiente y permisiva a la vez, que todo es posible, como sucede en la realidad.

Y, en el caso de delitos de los que causan la nefasta e indeterminada "alarma social", en momentos en los que los juicios paralelos se fomentan 
desde los medios de comunicación y las redes sociales, esta remisión a generalidades subjetivas, sin límites en los que encuadrar y sujetar el complejo probatorio, un auténtico golpe al Estado de derecho y un ataque a la neutralidad del Poder Judicial, cuya independencia pasa por eludir cualquier tipo de influencia que le haga convertirse en hacedor o asegurador de "justicias", siempre relativas y subjetivas. Al Poder Judicial compete aplicar la ley, no realizar funciones propias de ésta y competencia del legislador. ${ }^{6}$

No es posible una valoración de indicios, sujeta a principios estrictos, sin un mecanismo legal que ordene esta valoración y que garantice la vigencia previa de aquellos. No es posible una motivación, por muchas condiciones que se quieran asignar a la misma, si no existe un marco objetivo al cual sujetarla. No es posible, en fin, afirmar la presunción de inocencia a la par que ordenar la presencia de riesgos ciertos y de negar eficacia presuntiva inmediata a los indicios utilizados, sin establecer a la vez unas condiciones a las que los jueces hayan de someterse. Se repite que los mecanismos procedimentales son garantía de la decisión, siempre previos, preceptivos y que las operaciones intelectuales actúan en ese marco, no lo sustituyen y no pueden hacerlo sin generar efectos graves para el sistema. Y la realidad lo demuestra.

El proceso penal moderno, abandonando el Derecho procesal y con referencias a supuestos constitucionales que se estiman de mejor calidad -pero sin explicar la razón por la cual el procedimiento constituye una rémora o un obstáculo a la vigencia de los derechos fundamentales-, ha optado por referir todo el complejo decisional a valores de racionalidad y similares, los cuales operan sin referente normativo alguno y solo apegados a criterios de naturaleza no objetiva o normativa. La ponderación en el marco de la proporcionalidad no regulada, la argumentación mal aprendida y mecanismos similares han venido a imponerse sobre la ley y el Derecho procesal. Y cuando tales instrumentos no se llegan a comprender, se tornan peligrosos para la aplicación del derecho, al permitir, bajo apariencias externas, decisiones incompatibles con el sistema mismo, que

$6 \quad$ SERRA DOMÍNGUEZ, M: Entre otros muchos, advirtió sobre la influencia o presión sicológica y social de la población (en general), capaz de sustituir los presupuestos de la prisión provisional por sentimientos irracionales de vindicta, hasta tal punto que convertirían la medida cautelar en otra distinta, de seguridad. Seminario sobre detención y prisión provisional. Santiago de Compostela. 1995. Pág. 191. 
va evolucionando, curiosamente, hacia posiciones atentatorias al sistema garantista, exactamente lo contrario a lo pretendido. ${ }^{7}$

Por todo ello y para evitar y superar los riesgos que se afirman, los principios y el deber de motivación han de ser encuadrados en un marco conceptual al que se sujeten y que sirva de marco para su análisis, verificación y decisión. Que la adopción de la prisión provisional dependa de la valoración de indicios y que éstos no se adecuen a la forma de valorarlos y a los presupuestos de este complejo probatorio, es inexplicable cuando la prisión provisional se traduce siempre, materialmente, en una anticipación de la pena imponible, lo que comporta, como es lógico, una apreciación del material existente no solo al momento de apreciar el "fumus boni iuris", sino también de los elementos fácticos que posibilitan afirmar la presunción o riesgo que se presume.

Y ese marco existe en todas las legislaciones, ${ }^{8}$ que regulan la prueba indiciaria de un modo similar, que se adapta plenamente al procedimiento y razonamiento que el Juez debe seguir al momento de valorar la existencia y constancia de los indicios que le sirven para apoyar su presunción cautelar. Y ese marco, derivado de las exigencias del derecho a la presunción de inocencia, ofrece soluciones a una situación tan abierta y retórica como la que se aprecia en materia de prisión provisional. Y ese marco, a su vez, sirve para rechazar aplicaciones de sistemas inconstitucionales que se introducen en el proceso penal por vía de decisiones no sometidas a reglas objetivas.

Se trata de un marco, el de la prueba indiciaria que, obviamente, en este campo, no es, ni puede ser plenamente objetivo, pues la prueba circunstancial

7

Sobre la obligatoriedad del procedimiento, como garantía, vide PRIORI, G.: "El procedimiento preestablecido en la ley: la crisis de una garantía procesal y su rediseño en el Estado constitucional". En Proceso y Constitución. Las garantías del justo proceso. Palestra Editores, Lima, 2013. Págs. 585 y ss. En esta misma obra es conveniente consultar el trabajo de SUMARIA BENAVENTE, O: "El antiformalismo como presupuesto teórico para una tutela jurisdiccional efectiva”. En: Revista Jurídica Thomson Reuters, №35. Págs. 563 y ss. En el mismo se refiere la necesidad de distinguir entre forma y formalismo en un debate interesante, pero cuyos contornos no son fáciles de delinear, hasta el punto de que el antiformalismo, en nuestra opinión, ha excedido sus pretensiones lógicas en favor de la relegación de la forma, como garantía, cediendo ante una suerte de imperio de la determinación judicial libérrima.

$8 \quad$ En España se prevén en los arts. 385 y 386 de la Ley de Enjuiciamiento Civil, que establecen criterios amplios. Pero, la jurisprudencia penal las ha desarrollado de forma tan amplia y precisa, que supone, en el marco de aquellos preceptos, aplicables al proceso penal (art. 4 LEC), un marco objetivo suficiente para servir de cauce a la consideración de los riesgos cautelares propios de la prisión provisional.

Mucho más preciso es el art. 158 del NCPP peruano, que contiene los requisitos que han de verificarse en los distintos elementos del complejo probatorio. 
exige de una gran capacidad valorativa y casual; pero, la actividad judicial valorativa se enmarca en un procedimiento que disciplina elementos a los que se imponen requisitos objetivos, lo que significa una limitación de las facultades judiciales que pone freno a la subjetividad plena y a la discrecionalidad susceptible de transformar la prisión provisional en lo que no es.

Alejarse de lo que es debido, por regulado, carece de justificación. No imponer el respeto a los presupuestos de la prueba indiciaria, cuando se anticipa materialmente la sentencia, inexplicable y carente de justificación jurídica. Que una materia con respaldo legal y jurisprudencial se abandone a la discrecionalidad y solo se someta a criterios amplísimos, pero desprovistos de una cobertura jurídica existente y que evitaría los efectos más ilegítimos de la medida, solo puede responder a ausencia de criterio o a favorecer una discrecionalidad que, si bien podría funcionar en momentos de sosiego, no es conveniente en los de zozobra, en los que el mismo sistema acusatorio está sometido a los riesgos propios de una sociedad que ha optado por recuperar los viejos cánones del sistema inquisitivo.

En definitiva, la vigencia de los derechos a la presunción de inocencia y la libertad, así como el deber de motivación de lo que se adopta con base en una presunción, debe conducir a aplicar en esta materia las reglas de la prueba indiciaria y someter el control de las resoluciones a los requisitos que la ley y la jurisprudencia de desarrollo de las normas vigentes establecen.

Los efectos de esta conducta no son pocos, pues nunca lo son cuando, respetando la apreciación judicial, ésta se sujeta a reglas legalmente establecidas que no son de valoración, tasadas, sino objetivas, de requisitos. La motivación de las resoluciones judiciales, por muy amplia que sea, refleja siempre una forma de aprehender y entender una situación, subjetiva y particular e influida por la posición de quien la aprecia. De ahí, porque así lo impone la seguridad jurídica y es consecuencia de un sistema que se basa en la ley, única fuente del derecho procesal, que las decisiones judiciales hayan de basarse en las previsiones normativas, que conllevan un límite, un freno a la mera y simple apreciación personal.

Es el sistema mismo el que lo impone, el sistema que está cambiando al compás de la cesión de poderes a los tribunales que, por vía de reforzar su valoración subjetiva, están subordinando la ley a un papel secundario. Es el sistema mismo el que está cambiando por no entender que la ley es lo único a lo que se someten los tribunales y que la ley es la máxima expresión de la democracia, no la voluntad judicial, por muy motivada que ésta se presente externamente. 
Es el imperio de la ley, no el del Poder Judicial, el que expresa nuestro sistema. Alterarlo no es fruto de la improvisación. Concederles el poder de rehuir de la ley para, posteriormente, penetrar en su independencia, es el camino que se vislumbra. Demasiado simple como para no verlo.

\section{Presunción de inocencia y favor libertatis.}

En materia de prisión provisional rige el derecho a la presunción de inocencia ${ }^{9}$ que, aunque excepcionado por la misma naturaleza de la medida, debe mantener su vigencia al momento de interpretar las razones que justifican la restricción del derecho a la libertad $\mathrm{y}$, a su vez, ser compatible en sus valoraciones con un derecho que es innegable en una situación que se traduce en una anticipación de la prueba.

Sostener que este derecho no tiene aplicación al momento de acordar una medida de estas características, que tiene su base en un fumus boni iuris que el art. 728,2 LEC española entiende debe proporcionar un juicio provisional y favorable al fundamento de la pretensión que se suscite, no tiene una base suficiente y debe ser replanteado. ${ }^{10}$ La presunción de inocencia, cierto es, opera en el momento de la valoración de la prueba $\mathrm{y}$ en aquellos anteriores a esta operación, los objetivos que impiden que sean apreciados elementos que no tienen ese carácter o que son nulos por diversas razones, especialmente su ilicitud. Pero, la prisión provisional, por traducirse en una pena anticipada, no debe basarse en elementos que carezcan de esas exigencias propias de la prueba, siendo deudora de las mismas irregularidades e insuficiencias que vedan el acceso de determinados elementos a la valoración, entre ellos no tener tal carácter o ser ilícitos. Y, de igual modo, aunque sea provisionalmente, los datos utilizados para acordar una pena anticipada materialmente, deben tener una entidad y racionalidad próxima a la prueba. Lo contrario supone acordar una pena, sin sentencia y permitirla con menos requisitos que la derivada de una sentencia. La presunción de inocencia, en definitiva, no es solo regla de prueba, sino también, de tratamiento. ${ }^{11}$

9 Con absoluta rotundidad lo manifiesta DEL RÍO LABARTHE, ob.cit. Pág. 102, que manifiesta que esa infracción se produce siempre que la prisión provisional deje de comportarse como una medida cautelar y cumpla fines propios de la pena.

10 Así lo entiende DEL RÍO LABARTHE, ob. cit. Pág. 141. Y ASENCIO MELLADO, JM.: "La objetivación de los criterios para la apreciación del fumus boni iuris y el periculum in mora en la prisión provisional". En: Derecho y proceso. Libetr amicorum del profesor Francisco Ramos Méndez. Atelier, Barcelona 2018.

11 Sobre esta dimensión de la presunción de inocencia, vide FERNÁNDEZ LÓPEZ, M.: Prueba y presunción de inocencia. Iustel, Madrid 2005. Págs. 117 y ss. Sobre la 
La jurisprudencia del TC español mantiene una posición compleja acerca de la vigencia del derecho a la presunción de inocencia que, sin negar su influencia, la limita en forma en ocasiones de difícil comprensión. ${ }^{12}$ Llevar al derecho a la libertad todas las infracciones derivadas de la vulneración de los presupuestos de la medida reduce su operatividad y excluye de la motivación los requisitos propios del derecho a la presunción de inocencia, reduciendo la suficiencia a un análisis de la racionalidad y proporcionalidad en un ejercicio de ponderación que, siendo válido cuando de la libertad se trata, se ve artificialmente reducido. Una opción la de TC español que, a nuestro juicio, carece de explicaciones suficientes y que olvida o ignora la naturaleza misma de la prisión provisional como medida cautelar y el papel que juegan sus presupuestos en relación, siempre, con la presumida sentencia definitiva que se dicte, que no puede ser perdida de vista. La prisión provisional, cuando se desconecta de la condena futura, adquiere una autonomía que está en la base misma de su cada vez más extraño papel cautelar y el alcanzado, próximo a figuras que cumplen otras funciones.

Solo la vinculación, irrenunciable, entre medida cautelar y sentencia de fondo, aplicando a aquella las condiciones de esta última en la proporción posible por el momento procesal, garantiza la subordinación de lo que debe estar al servicio de un futuro que debe presumirse y que, para tal presunción, ha de asentarse en las condiciones propias de la condena que se anticipa.

Toda autonomía, se repite, conduce, como está sucediendo, a la prisión provisional a ser otra cosa, a poseer entidad propia, vida propia y cumplir fines que no son compatibles con su naturaleza constitucional. Cuando una medida deja de ser instrumental, pierde su carácter cautelar.

presunción de inocencia y la prisión provisional, en esta vertiente, vide CASTILLO ALVA, JL.: La presunción de inocencia como regla de tratamiento. Vol. I. Ideas Solución Editorial S.A.C., Lima 2018. Págs. 175 y ss.

12 Vide STC 32/1987, 10 de marzo; 34/1987, 12 de marzo que aplican este derecho en supuestos muy concretos. Por el contrario, es doctrina casi pacífica ya que la prisión provisional no afecta a la presunción de inocencia, llevando el análisis al cumplimiento de los requisitos exigidos para la restricción del derecho a la libertad (STC 128/1995, 26 de julio como paradigmática). Vide ORTELLS RAMOS, M. y TAPIA FERNÁNDEZ, I.: El proceso penal en la doctrina del Tribunal Constitucional (1981-2004). Thomson Aranzadi, Navarra 2005. Págs. 410 y ss. Sobre la STC español 128/1995, de 26 de julio, que conecta juicio de culpabilidad-presunción de inocencia-prisión provisional, vide TORRES-DULCE LIFANTE, E.: "Seminario sobre detención y prisión provisional". Santiago de Compostela. 1995.Págs. 259 y ss. 
En conclusión, las mismas prevenciones que se imponen al momento de la sentencia deben exigirse cuando se ha de acordar una medida que es una pena anticipada en su acepción material. No cabe desconocer el derecho fundamental a la presunción de inocencia y adoptar decisiones que lo vulneren sin atender a los requisitos legales y constitucionales que avalan la legitimidad de la prisión provisional tornándola una pena anticipada ajena a las condiciones de la pena misma. La resolución sobre la prisión provisional debe ser deudora de más requisitos que la pena misma, pues se basa en una presunción de culpabilidad que se opone a la de inocencia constitucional, de modo que solo es válida cuando sus presupuestos la justifican en el caso de modo absoluto y sin reservas. La prisión provisional es la mayor expresión de ataque a la presunción de inocencia, pues supone condenar sin condena previa.

$\mathrm{Y}$, en este sentido, la duda razonable sobre la coincidencia de los presupuestos que amparan la prisión provisional debe conducir a no acordar la misma, sino la libertad, máxime en un momento en el que el sujeto no ha sido declarado culpable, las pruebas no se han practicado y el Estado conserva y mantiene una serie de obligaciones que debe cumplir y cuyas deficiencias no pueden recaer sobre los ciudadanos, aunque éstos sean imputados. La duda, que cuando es fundada y elevada permite abrir el juicio oral, no autoriza una medida tan intensa como la prisión provisional, debiendo sus presupuestos ser acreditados en el caso y mediante los mecanismos ordinarios practicados conforme al medio de prueba que en su momento haya de servir para fundamentar una condena. Y ese principio del favor libertatis no solo, aunque suele ser lo normal, se aplica a la apreciación del periculum in mora, sino, en la medida adecuada, a la apreciación del fumus boni iuris, de los elementos de convicción que constituyen la base indiciaria de la imputación y que deben someterse, pues, no solo a las condiciones objetivas del derecho a la presunción de inocencia, sino a una probabilidad fundada de comisión de los hechos cuya duda razonable debe excluir la aplicación de una medida anticipatoria de la pena. ${ }^{13}$

En este sentido, los principios que informan la prisión provisional, de excepcionalidad, provisionalidad, proporcionalidad y necesidad, no son otra cosa -junto a garantías de vigencia de los derechos fundamentales en general-, que precisiones concretas del derecho a la presunción de inocencia, determinaciones que limitan el poder del Estado y que obligan a éste a asumir sus propias obligaciones frente a un poder absoluto incompatible 
con los valores de un Estado de derecho. Los principios que rodean a la prisión provisional no solo protegen la libertad, sino a su vez, la presunción de inocencia.

Que, a su vez, afectan al derecho a la libertad, es evidente, pero en caso alguno puede ser entendido que es solo este último derecho el que está en juego. Cuando la excepcionalidad se analiza solo desde la perspectiva de libertad, padece o se ve constreñida por una valoración muy reducida.

Ambos derechos se ponen en evidencia y ambos deben ser respetados, cada uno en función de su naturaleza y exigencias constitucionales y legales, pues no todo es derecho constitucional, siendo el procesal, cuando de una medida de este carácter se trata, ineludible.

Llama la atención, cabe indicar, por último, que se rechace aplicar la presunción de inocencia al momento de adoptar la medida, pero que se atienda cuando del régimen carcelario de preventivos se trata, pues estos últimos, merced a que no han sido condenados, no disfrutan de los beneficios derivados del tratamiento penitenciario dispensado a los penados. Es lógica esta postura, pero choca con la negativa a aceptar que aquel derecho opere en lo que es presupuesto del internamiento, pero sí posteriormente. $\mathrm{O}$, lo que es lo mismo, que sea eficaz solo en lo que perjudica al imputado. ${ }^{14}$ Una contradicción ésta que debería llevar a pensar a quienes niegan lo que parece innegable cuando beneficia a la libertad y lo asumen, por el contrario, cuando la restringe.

2. La inexistencia de un riesgo cero al momento de adoptar la prisión provisional.

No hay, ni es posible en el proceso penal jamás un riesgo cero, un riesgo inexistente de que no se produzcan conductas que el sistema de medidas cautelares viene a prevenir. Y esta idea es central para discernir sobre la valoración de los presupuestos que autorizan el acuerdo de la medida, pues normalmente se confunde o se omite considerar partir de este dato absoluto e irrenunciable. Y esa confusión está en la base de decisiones que invierten la finalidad de la medida en un proceso penal acusatorio.

Los riesgos existen y se mantienen siempre en mayor o menor medida, no pueden ser previstos con certeza absoluta, ni evitados jamás con seguridad plena. Tanto, como el de equivocación judicial al momento de valorarlos. No es posible, pues, que ante el menor riesgo intuido o posible, 
aunque sea en términos de probabilidad, incluso intelectual, se adopte una medida cautelar de la gravedad de la prisión provisional. Pues, se insiste en la idea, el riesgo ideal siempre permanece y es imposible de eludir. Cuando el Estado dicta esta medida ante la mera sospecha de la eventualidad de un riesgo ideal, recurre a un sistema cautelar que parte de principios diametralmente opuestos a los propios del proceso acusatorio. Es decir, frente a la excepcionalidad, se acude a la automaticidad, de manera que ante la sospecha de un delito se acuerda la privación de libertad, medida que se considera que garantiza plenamente el proceso, sin atender a que el riesgo sea meramente teórico o abstracto y bastando con que sea solamente posible desde la lucubración intelectual y olvidando los deberes que el Estado debe asumir de garantizar la sujeción de los sujetos al proceso. Dictar la prisión provisional desde la consideración de que el riesgo teórico permanece, no es suficiente, pues nunca es evitable ese riesgo abstracto. Afirmar la existencia de un riesgo supuesto, especulativo, sobre la base de criterios generales, lleva derechamente a la automaticidad de la prisión provisional, a la afectación de la excepcionalidad, de la necesidad y de la proporcionalidad y directamente a vulnerar el derecho a la presunción de inocencia.

De ahí que la prisión provisional opere con tanta rigidez y que sea tan difícil en ocasiones evitarla cuando la pena previsible es elevada, aunque concurran datos que avalan la vocación de permanencia del sujeto ante el tribunal competente. $\mathrm{O}$ que, en ciertos delitos, con base en criterios estandarizados, se proclame un peligro de reiteración delictiva casi vinculado a la naturaleza de los hechos presuntamente cometidos.

$\mathrm{Y}$ que, en estos casos, se acuerde la prisión provisional de forma automática al prever que el riesgo de fuga o de repetición delictiva subsisten y que haya de ser el imputado el que acredite lo contrario, en una labor imposible, pues los hechos negativos no pueden ser probados (negativa non sunt probanda).

El TS español, en su reciente auto de fecha 4 de diciembre de 2017 (Fundamento tercero), ha visto claro que esa eventualidad de inexistencia de peligro es imposible y en esta resolución declara que jamás se puede tener una certeza absoluta sobre la elusión de los riesgos cautelares. Esa certeza es idealmente imposible. De modo que sujetar una decisión de prisión a la erradicación de toda eventualidad o posibilidad de peligro, supone convertir la medida en automática. 
"De otro, porque todos ellos cuentan con un profundo arraigo personal, laboral y social en la Comunidad Autónoma de Cataluña, y visto además que su disposición por atender los llamamientos judiciales que se les han cursado hasta ahora, si bien no aporta ninguna certeza para el futuro, sí es el empírico reflejo de que libremente rechazaron la huida que emprendieron otros encausados".

Es decir, que los datos aportados bastan para acreditar un presente, una conducta avalada por un actuar determinado, que debe prevalecer sobre una hipótesis de futuro que el TS estima como imposible desde la certeza. Frente a un dato empírico, la sujeción al proceso, no puede alzarse otro meramente hipotético, apoyado en el temor a la frustración, genérico, que, sin más explicaciones que ese mismo temor, sirva de base a una medida de tanta gravedad. Como se verá, en el juego de las alternativas posibles al valorar los indicios se haya la respuesta a estos dilemas tan frecuentes, como carentes de respaldo lógico y legal.

Entender este dato, esto es, que no puede existir una situación en la que el riesgo hipotético sea cero y que no puede ser excluido en caso alguno de forma total, es esencial a la hora de decretar la prisión provisional ajustándola a los principios que la presiden y respetando estos. Excluir o exigir la exclusión de cualquier riesgo hipotético, optando por la prisión provisional ante la hipótesis de su verificación, significa transgredir la regla de la excepcionalidad y, a su vez, las de necesidad y subsidiariedad. Afirmar que la libertad o las medidas alternativas no erradican plenamente el riesgo teórico, supone excluir de hecho su aplicación en todo caso o, al menos, someter la prisión provisional a la mayor o menor capacidad de asumir las consecuencias de cada tribunal o juez, al carácter de cada juzgador. Algo que debe evitarse por sus nefastos efectos en un mundo dominado por los juicios paralelos, las redes sociales en alza y la vocación inquisitiva de una sociedad que ha vuelto sobre sus pasos algunos siglos atrás. En ocasiones, por los llamados "jueces estrella", fruto, precisamente, de un mundo en el que la imagen se propaga con velocidad y la sociedad aúpa a quien aparece como "justiciero", incluso contra la ley.

3. La indebida consideración de las presunciones en la adopción de la prisión provisional.

El razonamiento acerca de la procedencia de la prisión provisional no es otra cosa que una presunción, pues el acuerdo de prisión provisional sobre la base de indicios funciona como tal, de modo que la motivación y proceso 
deductivo han de sujetarse a las reglas de esta forma de proceder. Negar que lo sea o no someterse a las reglas de este complejo probatorio, cual sucede, no tiene explicación suficiente y deja muchos espacios abiertos para la duda.

Solo aplicando las normas de este medio de prueba, se puede garantizar una expresa decisión sobre la existencia de los riesgos, eludiendo criterios abiertos y negativos que presuman lo que debe probarse y solo desde las condiciones de esta prueba se puede asegurar que las medidas alternativas se mantengan en un nivel de aplicación adecuado a los principios que informan la adopción de esta gravísima medida cautelar.

Las reglas que presiden la prueba indiciaria, en su triple consagración, implican la certeza de la consideración de los indicios como tales, la de su entendimiento conjunto y relacionado con una conclusión y la de una inferencia razonable, que descarte alternativas posibles de modo expreso y que evite, por vía indirecta, presunciones automáticas iuris et de iure o iuris tantum.

Frente a la ambigüedad de las declaraciones jurisprudenciales, en cierto modo retóricas y ajenas a mecanismos de control que la ley contempla, se debe sujetar el razonamiento indiciario que subyace a la prisión provisional al complejo de la prueba indiciaria, que contiene todos y cada uno de los elementos que el Juez valora en trance de acordar la prisión provisional y, a su vez, ofrece un marco de certeza, objetividad y control de los acuerdos judiciales. Porque, sin duda, el Juez, cuando valora los indicios en los que se apoya para concluir su presunción sobre los riesgos que quiere prevenir, lo hace o debe hacerlo de la misma forma en que se aprecian los indicios para concluir una condena. Siendo así, no se entiende que el mecanismo indiciario no sea aplicado con todo rigor cuando de adoptar la prisión provisional se trata y se reduzcan las exigencias a un complejo que garantiza el acierto.

La aplicación de las normas sobre la prueba indiciaria sirve para excluir absolutamente el llamado peligrosismo procesal, consistente en considerar como punto de partida y presunción abstracta la existencia de riesgos en ciertos delitos y sujetos, de modo que no es el peligro lo que se acredita, sino, al contrario, la insuficiencia de ciertas medidas para excluir lo que solo se toma como punto de partida. Una presunción inicial y abstracta que debe desvanecerse, ante la obligación contraria de acreditar el peligro en el caso concreto. 
La aplicación de la prueba indiciaria tiene, como principal beneficio, la exclusión de mecanismos presuntivos que invierten la carga de la prueba, pues es el riesgo lo que deberá probarse, no su inexistencia. Y este objetivo ya justifica con creces lo que se propone.

Los riesgos, si se aplican las reglas de la prueba indiciaria, desde la inevitable existencia de su coincidencia genérica, no pueden ser considerados en abstracto, pues en abstracto siempre permanecen y tampoco ser analizados al margen de las fórmulas que la ley estima oportunas para su desestimación en el caso, las cuales tampoco son ajenas a los deberes del Estado de asegurar la presencia del imputado en el proceso sin sucumbir a presunciones generales de elusión del proceso.

A. La exclusión de las presunciones iuris et de iure.

No son admisibles en el proceso penal, en ningún caso y situación, las conocidas como presunciones iuris et de iure, es decir, aquellas en las que, verificados los indicios, la conclusión es automática, sin que sea posible o demandable prueba en contrario. Su inconstitucionalidad en el proceso penal deriva de la vigencia del derecho a la presunción de inocencia, opuesto a una inferencia de culpabilidad. Y así lo estableció el TS español, en su sentencia 105/1988, de 8 de junio entre otras muchas.

La prisión provisional se ha apoyado durante siglos en este tipo de presunciones, pues cuando la medida devenía automáticamente y de forma obligatoria ante la presencia de determinados hechos, indicios, lo que se hacía era aplicar una presunción legal iuris et de iure. De esta forma, atacando el derecho a la presunción de inocencia derechamente, se producía una degradación de la prisión provisional como medida cautelar y su aproximación a figuras meramente retributivas de forma anticipada.

Es evidente que la prisión provisional no puede adoptarse automáticamente ante la presencia de determinados indicios sin más razonamiento en el caso. Cuando se hace depender de la concurrencia, por si solos, de elementos, tales como la gravedad de la pena, la capacidad económica etc., se está actuando al modo de aplicación de una presunción legal iuris et de iure, pues el riesgo se presume directamente, genéricamente y en abstracto, sin más explicaciones que la presencia misma de los indicios legales o extralegales.

De la misma forma se actúa cuando se desiste de aplicar una medida alternativa por el solo hecho de considerar que, en abstracto, la prisión 
provisional garantiza en mayor medida un riesgo eventual, no motivado, ni concretado salvo en la presencia, no razonada, de indicios que por sí solos se hacen base de la inferencia. Una presunción que no admite prueba en contrario, pues es totalmente cierto que la prisión provisional garantiza en mayor medida la presencia del imputado que otra distinta y de menor intensidad.

En definitiva, concluir que el riesgo existe porque se dan nominalmente los indicios, es tanto como construir presunciones legales. No aplicar una alternativa porque la prisión provisional es más radicalmente aseguradora, equivale a lo mismo.

La tendencia a la automaticidad es expresión, pues, de una incorrecta atención a la naturaleza de las presunciones y a la entrada en el proceso de las legales, si bien disimuladas tras motivaciones vacías de contenido real.

Los principios informadores de la prisión provisional encuentran su expresión directa en este caso al aplicar al razonamiento judicial las reglas de la prueba indiciaria, de modo que su infracción revela que en su lugar se opta por acudir a una presunción legal iuris et de iure, constitucionalmente prohibida. Mediante el mecanismo de aplicar las normas de ese conjunto probatorio, es fácil evidenciar en cada caso la infracción de los principios que deben ser respetados al momento de dictar o no la prisión provisional.

Cuando una decisión se limita a expresar la concurrencia de alguno de estos motivos o varios, sin explicitar la razón por la cual debe prevalecer la pérdida de libertad, está aplicando, indirectamente, una forma de actuar similar a la propia de las presunciones legales iuris et de iure, pues no cabe probar lo contrario cuando el juez afirma un riesgo sin elementos de acreditación distintos a considerar, en general y como mera abstracción, que existe un riesgo. Y ello sin hablar de la inversión de la carga de la prueba, contraria al derecho a la presunción de inocencia, que supone que el imputado haya de acreditar un hecho negativo, su vocación de sujeción al proceso y que las acusaciones se limiten a afirmar un riesgo genérico y automático que se presume absoluto.

Este tipo de resoluciones que entran en razonamientos aparentes y circulares, no son admisibles en el marco de la prueba indiciaria y, aunque revestidos de apariencia, encubren una forma de actuar propia de otros sistemas, los de la prisión provisional obligatoria y automática.

No es extraño en estos casos y los ejemplos son frecuentes, que la misma resolución haga referencias constantes a la gravedad del delito, 
al daño social producido y a la entidad de éste, lo que revela que la prisión provisional es, en realidad, una vez hecha dependiente de la mera concurrencia formal de los indicios que la ley expresa, una resolución cuya naturaleza jurídica no es cautelar, sino preventiva o anticipatoria de los fines de la pena. Y en este sentido se ha expresado el TC español en su sentencia, entre otras muchas, 66/1997, de 7 de abril.

"En esta situación, pues, no es que la referida argumentación de la Audiencia se revele ilógica o arbitraria, sino que resulta insuficiente para sostener una medida que por su gravedad y por la condición de inocente de su destinatario debe ser sólo utilizada excepcional, subsidiaria, provisional y proporcionadamente. No se trataba, pues, de mostrar que la posibilidad de fuga del imputado -y, con ello, la medida de prisión"no era descabellada", sino, acaso al contrario, de enervar con un razonamiento explicitado y objetiva y subjetivamente particularizado la fuerte presunción a favor de su libertad. De ahi que, en suma, al igual que sucedia en el supuesto que dio lugar a la STC 128/1995, el mantenimiento de la prisión provisional sin ulteriores matices y la soledad argumentativa de la motivación relativa a la gravedad de la pena, siquiera formalmente solicitada, conviertan a los Autos recurridos en expresión larvada de un automatismo en el decreto de la prisión provisional abiertamente contrario a los principios ya indicados que deben presidir la institución. Procede en consecuencia, el otorgamiento del amparo en este punto".

B. La improcedencia de considerar los indicios como presunciones iuris tantum.

El riesgo, como ya se ha sostenido, existe siempre teóricamente, de modo que es deber judicial motivar el que se hace presente en el caso, de manera individual y concreta $\mathrm{y}$, a la vez, descartar que sea posible eludirlo mediante medidas alternativas, las cuales siempre implican una actividad estatal, ordinaria, que entra de lleno en el terreno de sus deberes y que no puede ser obviada haciendo recaer en el imputado la carga de acreditar la inexistencia de peligro alguno -tarea imposible cuando se parte de una presunción de riesgo asignada a delitos determinados-, e, incluso, la de asumir la inefectividad del Estado en orden al cumplimiento de sus obligaciones administrativas y procesales.

La carga que se hace recaer sobre el imputado es excesiva, desproporcionada, contraria al derecho a la presunción de inocencia y 
supletoria de las deficiencias del Estado en el cumplimiento de sus mínimas obligaciones. Un dato a tener en cuenta.

A diferencia de las presunciones iuris et de iure, pero operando de forma muy similar, casi exacta, aunque bajo apariencias que quieren apartarse de esta calificación, la prisión provisional puede hacerse depender y así suele suceder, de la presencia en el caso de unos indicios que se afirma que en general revelan un peligro, peligro que se asume como cierto y que se presume como tal de forma genérica. No obstante, este peligro no se expone de forma automática -se insiste, solo en apariencia-, sino que se aduce que el resto de indicios concurrentes en el caso no acreditan la desaparición de un riesgo presumido en abstracto y por la sola presencia de indicios considerados de forma automática.

En conclusión, se acuerda la prisión provisional porque, a partir de indicios legales asumidos estrictamente y sin valoración adecuada al caso y particular, se afirma el peligro abstracto para, a continuación, asegurar que el resto de indicios, cuya aportación se impone al imputado, no sirven para desacreditar ese peligro idealmente considerado. Una construcción típica de presunción iuris tantum en la que la conclusión o hecho presumido no se afirma a partir de unos indicios y un nexo causal entre los datos objetivos y el hecho afirmado, sino que este último se construye mecánicamente en tanto derivado de la constancia de hechos indiciarios determinados. Un razonamiento que el TC español, en la sentencia 66/1997, rechaza de forma expresa.

Ese razonar no constituye la motivación que impone el derecho a la presunción de inocencia. Porque, partir de la existencia de un riesgo por el hecho de que coincide un dato determinado, supone afirmar una presunción de manera automática, presunción que no se construye razonadamente, sino que, por el contrario, ha de descartarse en el caso. Se invierte, pues, la carga de la acreditación de los peligros, no siendo las partes acusadoras quienes deban probar el riesgo, sino las acusadas o imputadas las que han de acreditar lo contrario, esto es, la inexistencia de un peligro. Ese es el resultado de la práctica en que se incurre. Los riesgos se elevan a la consideración de presunciones "iuris tantum".

Se hace recaer en el imputado una prueba diabólica, en tanto, como se ha dicho, la presencia de un riesgo teórico o abstracto es siempre inevitable e imposible de eludir (ATS español de fecha 4 de diciembre de 2017). Si se afirma un riesgo, desde posiciones de peligrosismo procesal ante hechos determinados que han generado alarma social $-\mathrm{y}$ así se suele afirmar 
bajo eufemismos-, y se exige acreditar que el resto de indicios prueben absolutamente la desaparición de cualquier riesgo y más el construido sobre la base de afirmaciones teóricas, se está llevando al imputado a una situación imposible de remediar. Y, en todo caso, sujeta a la mera creencia judicial y a su voluntad incontrolada e incontrolable. O controlable solo desde el mero subjetivismo o criterios abstractos que, siendo útiles una vez se han superado las exigencias legales, no pueden sustituir a estas últimas. El razonamiento no puede suplir a la ley y a sus condiciones objetivas y este proceso que va de la ley al Juez se va imponiendo paulatinamente en un sistema refractario a este actuar, generándose con ello consecuencias gravosas para el mismo sistema acusatorio y los derechos y garantías del imputado. La racionalidad no puede sustituir a las condiciones objetivas del material sobre el que recae la motivación, ni la corrección argumentativa constituir una regla en sí misma que excluya las prescripciones legales.

No basta, pues, afirmar que existe un riesgo sobre la base de datos genéricos que la misma ley contiene como advertencia de ese riesgo general. En tanto el riesgo existe en términos abstractos, lo que debe acreditarse es que existe en concreto y que no puede ser eludido por medio de otras medidas alternativas. Esto es, no que no se ha probado su desaparición, que no se ha descartado, sino que el mismo existe en el caso y que no se puede eludir por medio de otras medidas. No es una presunción iuris tantum la que surge de la coincidencia de ciertos indicios que permitan afirmar sin razonamiento concreto en el caso un peligro; esa presunción es inconstitucional.

Es el método mismo, implícito en la desatención al complejo constituido por la prueba indiciaria, el que genera estas consecuencias. De aplicarse este último, es evidente que habría que acreditar positivamente los indicios y vincularlos a la conclusión afirmando una consecuencia una vez descartadas las alternativas varias. Por el contrario, cuando se actúa al margen de este procedimiento legal y adecuado, se parte de presunciones, de conclusiones no motivadas en el caso y se indaga en los indicios para valorar si estos, en el caso, desvirtúan esa presunción que, por tanto, es legal y funciona como tal, aunque sea iuris tantum. Y esta es la forma de proceder ordinaria en la actualidad, la que debe superarse para que la prisión provisional sea una medida cautelar y cumpla los fines propios de este carácter.

Lo mismo debe decirse de la aplicación de medidas alternativas, menos intensas. Partir de la existencia de un riesgo y asegurar que solo 
la prisión provisional lo evita, es tanto como atentar a la excepcionalidad. $\mathrm{Y}$, naturalmente, es elevar una obviedad sobre las exigencias legales, una evidencia sobre los preceptos derivados de la naturaleza excepcional de la prisión provisional, reforzados por esa imposición del riesgo cero teórico y por la efectividad absoluta del sistema sobre sus criterios garantistas.

La ley consagra medidas alternativas que parten siempre de aceptar la presencia de peligros, pues en caso contrario lo procedente sería la prisión provisional automática. En consecuencia, se debe partir a la hora de valorar su procedencia de dos datos: el primero, que los riesgos existen, lo que debe ser acreditado; el segundo, que ha de motivarse la improcedencia o insuficiencia de las medidas alternativas para soslayarlo. No se puede, pues, partir de la noción de que la prisión provisional asegura el riesgo absolutamente y de que las medidas alternativas solo son aplicables cuando se acredita plenamente la evitación del mismo. Y hacerlo de modo genérico, abstracto, sin más razonamiento que la mayor utilidad de la prisión provisional. ${ }^{15}$ Ninguna duda cabe de la absoluta eficacia de la prisión provisional, pero partir de esa eficacia y exigir que en el caso se pruebe la misma de las medidas alternativas, supone atentar a la excepcionalidad, que exige lo contrario, esto es, la necesidad absoluta de la prisión provisional.

Aceptar el riesgo teórico, supone admitirlo y adoptar la medida que lo eluda dañando lo menos posible a los derechos del imputado. No debe probarse que las medidas alternativas son igual de eficaces, lo que resulta imposible, sino que garantizan en el caso las funciones previstas, aun aceptando un nivel de riesgo siempre posible. Lo esencial es atender a los datos presentes, sin especular sobre hipótesis futuras desprovistas de hechos en los que basarlas, pero anteponiéndolas a la realidad misma. De aplicase la prueba indiciaria, esa conclusión carecería de indicios en que apoyarse, pues los indicios son elementos objetivos, no simples sospechas o elucubraciones.

No solo hay que probar el peligro en el caso, sino, a su vez, que las medidas alternativas son insuficientes y esa insuficiencia tampoco se puede hacer depender de la existencia de un riesgo genérico que se afirma idealmente y que se entiende solo remediable de forma absoluta. El Estado

15 BARONA VILAR, S.: Seminario obre detención y prisión provisional (Obra colectiva). Santiago de Compostela. 1995. Pág. 150, destaca la necesidad de que los tribunales apuesten por un entendimiento adecuado del principio de proporcionalidad al punto de aplicar las medidas alternativas, pues de esta consideración depende mucho la virtualidad misma de estas resoluciones. 
no puede eludir los riesgos de forma absoluta mediante actitudes contrarias a los derechos fundamentales. Vale aquí reproducir la doctrina que afirma que en el proceso penal no se puede obtener la verdad a cualquier precio, lo que, trasladado a la materia que nos ocupa, exige que el Estado pondere los valores en juego.

Afirmar que la gravedad de la pena o la capacidad de viajar al extranjero, por ejemplo, son motivos que justifican una prisión provisional no es suficiente en un sistema que obliga a la excepcionalidad y a la motivación, pues la concordancia de tales motivos genéricos, por otra parte comunes, no hace otra cosa que confirmar un riesgo también genérico, inevitable y que es común en todo razonamiento cautelar que parte siempre de un peligro como presupuesto, que debe ser prevenido, pero que no es automático, ni genérico. Automaticidad absoluta que en nada difiere de los sistemas de prisión provisional obligatoria.

Afirmar estos riesgos cuando, en el caso, se ha verificado una conducta que no coincide con las valoraciones judiciales abstractas, supone actuar sin bases objetivas y anteponer criterios subjetivos a los que deben presidir una materia tan sensible para el sistema de derechos fundamentales y el proceso penal acusatorio.

\section{Los deberes y obligaciones del Estado y la prisión provisional.}

Todas las leyes que regulan la prisión provisional son conscientes de una realidad, ya mencionada y que en este lugar debe repetirse: la de presencia ineludible de riesgos teóricos en todo caso que, cuando se desarrolla la regla de la excepcionalidad, han de ser tenidas en cuenta al momento de regular las medidas alternativas que los moderen. Porque, es evidente que, incluso superada la verificación de tales riesgos en términos de mera abstracción, estas resoluciones que se adoptan para sustituir a la privación de libertad, siempre poseen una menor entidad aseguradora del proceso.

Las medidas alternativas, por tanto, debido a esa mayor presión sobre los derechos y la libertad que garantizan, solo restringida, no privada, exigen que el Estado adopte conductas, por otra parte, obligaciones genéricas en muchos casos, pero de cuyo cumplimiento depende la eficacia misma de las medidas alternativas. Por tanto, se puede afirmar que la garantía de los derechos de los imputados es deudora del cumplimiento por parte del Estado de sus propias obligaciones, las cuales, ordinariamente, exigen de 
inversiones presupuestarias y de un grado de eficacia determinado de sus funcionarios públicos.

Es sabido que, en un Estado democrático, los derechos fundamentales de los que son titulares las personas individualmente consideradas, obligan al Estado a su protección. En un modelo social el propio Estado ha de hacer frente a los efectos que produce la violación de derechos cuando ésta provenga del incumplimiento por su parte de los deberes que le incumben.

De este modo, que el Estado los deje de verificar no puede traducirse en una mayor invasión en el marco de esos derechos por el mismo Estado infractor. Si quien debe ampararlos deja de hacerlo, habrá de asumir las consecuencias y, en ningún caso, hacer recaer en los ciudadanos los efectos de su ineficacia o pasividad obligada. Podría hablarse, en todo caso, de un reparto de modo proporcional, pero nunca de que el ciudadano soporte en exclusiva las deficiencias de la actuación del Estado viendo afectada su libertad por la ineficacia de este en el cumplimiento de sus obligaciones más elementales.

Cuando el riesgo de fuga se hace depender de elementos genéricos, que afectan a las obligaciones del Estado, como son la guardia de las fronteras o el control de los movimientos de los ciudadanos; cuando el riesgo de fuga deriva, admitido incluso el arraigo, de esas valoraciones genéricas que dependen del cumplimiento por parte del Estado de sus deberes mínimos, no se puede acordar la prisión provisional para redimir las deficiencias del Estado. Pues, si el riesgo de fuga depende, por ejemplo, como se suele indicar mecánicamente, solo de una eventualidad genérica, la capacidad económica y la posibilidad de viajar al extranjero, no concretada ni manifestada en ausencia de arraigo, que se reconoce existente, es el Estado el que viene obligado a garantizar sus obligaciones, los controles fronterizos o el de los movimientos del afectado mediante los artefactos mecánicos existentes hoy en día y cuyo coste debe asumir frente al de la privación de libertad. En definitiva, si el éxito de una medida viene condicionado por el esfuerzo del Estado o, mejor dicho, por el cumplimiento de sus deberes como tal, no puede el imputado ser gravado por el desistimiento de aquel de sus funciones, por la causa que sea. Y mucho menos puede argumentarse que la libertad debe padecer cuando el Estado no asiste sus competencias ordinarias por falta de fondos, de previsión presupuestaria, por defectos organizativos. Un Estado social está y debe estarlo, comprometido con los derechos, que se constituyen en obligaciones frente a él y ha de asumir las consecuencias de no poder protegerlos garantizando su ejercicio, 
sin menoscabarlo por decisiones, como las presupuestarias, siempre discrecionales en tanto atienden a las preferencias que deciden los órganos competentes.

Es decir, el riesgo de fuga no puede quedar remediado por medio de la prisión provisional cuando es evitable mediante sistemas de control, sencillos y fáciles de implantar por el mero hecho de no disponer de los mismos. La falta de previsión presupuestaria en parcelas tan elementales no es motivo suficiente para ingresar en prisión a una persona cuyo control podría fácilmente ser efectuado mediante una simple pulsera electrónica.

Del mismo modo, la prisión domiciliaria, que favorece además de la libertad el derecho a mantener la vida privada y familiar entre otros, no puede dejar de decretarse por falta de instrumentos de control eficaces por el mero hecho de no disponer de ellos.

Evidentemente, se trata de aquellos casos en los que, a partir del análisis de los presupuestos de la medida, se ha evidenciado la suficiencia de una medida alternativa sujeta a control por medio de un instrumento determinado. No, por supuesto, cuando se considere que la medida menos intensa es insuficiente para asegurar el proceso.

Cuando un Estado opta por la prisión provisional ante la presencia de hechos objetivos, genéricos, como son la tenencia de medios económicos o los viajes al extranjero que acreditan la posibilidad de salir del país, enunciados en abstracto como riesgos eventuales, está afirmando indirectamente cosas que afectan a su imagen pública e internacional. Una, que cualquier persona con cierto poder económico, aunque arraigado o afincado en el país, debe ser privado de libertad en todo caso; dos, que no confía en su propia organización administrativa o policial, en sus métodos de control, en su policía y en sus autoridades fronterizas, que éstas son deficientes, lo que, naturalmente, genera inseguridad cara al exterior.

No es la imagen de eficacia lo que se transmite hacia el exterior, sino precisamente la contraria, la de insuficiencia para hacer frente a su papel como Estado moderno, garantista de la igualdad y respetuoso con la legalidad, además de organizado con la eficiencia exigible. Si cualquier persona que posee medios económicos o, mejor dicho, tiene bienes en el extranjero, pudiendo ser incluso un extranjero inversor, se va a ver expuesto a la prisión provisional en todo caso ante la falta de medios para aplicar medidas alternativas, es evidente que padecerá la inversión en el país, la seguridad de quienes quieran hacerlo, el riesgo de verse afectado por procesos que pudieran incoarse sobre datos no siempre adecuados para 
fines espurios. $\mathrm{Si}$, ese mismo Estado, afirma que carece de medios para impedir la fuga o para evitar la frustración de la investigación por carecer de sistemas de investigación tecnológicos, estará exponiendo públicamente sus carencias e ineficacia y sembrando una imagen y percepción de Estado deficiente y poco confiable.

En definitiva, la adopción indiscriminada de la prisión provisional no genera la idea de Estado fuerte y sometido a la ley, sino exactamente la contraria, la de Estado represor, poco respetuoso con los derechos humanos, escasamente atractivo para las inversiones y susceptible su Poder Judicial de aceptar intereses incompatibles con el proceso penal y la Justicia independiente.

No es posible, ni aceptable, acordar la prisión provisional haciendo al imputado deudor de la falta de eficacia del Estado en el cumplimiento de sus deberes, dentro de los cuales está el de garantizar sus fronteras y los movimientos de sus ciudadanos cuando se sujetan a condiciones que les obligan a la permanencia en un lugar determinado o la prohibición o prohibiciones de desplazamiento o acercamiento. Si la ley contiene medidas alternativas que posibilitan la libertad restringida, es porque el Estado dispone de medios para asegurar su eficacia, pues lo contrario sería equivalente a consagrar medidas solo teóricas. Cuando el Estado regula medidas alternativas, se compromete a garantizar su cumplimiento, sin que su ineficacia pueda dar lugar a que el imputado soporte las deficiencias en su libertad. Regular medidas, que obligan e ignorar las previsiones que las hagan ciertas, es tanto como legislar sobre el papel lo que, en materia de derechos fundamentales, por su carácter vinculante, merece ser objeto de rechazo y aplicación preferente del derecho sobre los aspectos secundarios que lo frenan en su realidad.

4. La prisión provisional y la prueba indiciaria. La aplicación de la ley y la jurisprudencia desarrollada en torno a este complejo probatorio.

La prueba indiciaria, aplicable en su consideración como mecanismo de valoración más allá de la sentencia, constituye un complejo probatorio por el cual el Juez alcanza la convicción respecto de un hecho sobre la base de otros hechos indirectos a través de una actividad intelectual que vincula racionalmente los indicios con el resultado inferido. Esa vinculación o nexo causal o lógico es determinante y propio de esta prueba, pues, aunque 
se verifique también en los casos de prueba directa, aquí alcanza una mayor significación. ${ }^{16}$

La prueba indiciaria se regula en su contenido y requisitos en diversos preceptos de cada legislación. En España se hace en el art. 386 LEC y en Perú, en el art. 158,3 NCPP, precepto que conviene tener presente por su carácter pedagógico, mayor que el de otros ordenamientos, en tanto la misma ley desarrolla el complejo probatorio designando los telementos que lo caracterizan y que aquí reducimos a dos al elaborar el referido a los indicios de forma que integre también a las condiciones exigidas a éstos. No obstante, no debe perderse de vista que la prueba indiciaria, prueba reina en el proceso penal moderno una vez desaparecida la obligación propia del inquisitivo de exigencia de pruebas directas, fue desarrollada por la doctrina y, posteriormente, por la jurisprudencia, siendo al final aceptada por la ley que poco o muy poco ha aportado a su diseño original por parte de la doctrina científica.

En consecuencia, basta para el entendimiento y comprensión de esta prueba con el análisis doctrinal del concepto, pues el mismo ha sido acogido plenamente por la jurisprudencia, que suele ser receptora de los avances que se producen en la Academia, no al contrario, salvo contadas ocasiones de magistrados fuertemente implicados en la investigación científica.

Descartada en páginas anteriores toda opción que signifique que la prisión provisional pueda convertirse o supeditarse a la admisibilidad de presunciones legales iuris et de iure o iuris tantum, directa $o$ indirectamente, se debe acudir, a los efectos de establecer un mecanismo legal que impere en las decisiones judiciales, a uno regulado o legalmente aceptado, desarrollado en sus requisitos por la jurisprudencia, trabajado por la doctrina científica, cierto, seguro y que ofrezca un marco adecuado al órgano judicial y a los imputados.

La aplicación de la prueba indiciaria, así, en todo lo que no sea aplicable exclusivamente al momento de la sentencia, que es escaso como se verá, ofrece un marco estable y se adecua plenamente a las operaciones

$16 \quad$ Sobre prueba indiciaria vide, especialmente: SERRA DOMÍNGUEZ, M.: "Función del indicio en el proceso penal". En: Estudios de Derecho Procesal. Librería Bosch, Barcelona 1969. Págs. 699 y ss. PRIETO-CASTRO, L.: Tratado de Derecho Procesal Civil. Aranzadi, Navarra 1985. Págs. 635-649 y 702 y ss. GARCÍA CAVERO, P.: La prueba por indicios en el proceso penal. Editorial Reforma S.A.C., Lima 2010. ASENCIO GALLEGO, JM.: "Presunción de inocencia y presunciones iuris tantum en el proceso penal". En: Revista General de Derecho Procesal. No 36, 2015. ASENCIO MELLADO, JM.: "Presunción de inocencia y prueba indiciaria”. En: Cuadernos de Derecho Judicial. Madrid, 1992. Págs. 163 y ss. 
que legalmente se exigen para decretar la medida restrictiva de la libertad, así como responde plenamente a la vigencia efectiva, no meramente formal, de los principios que informan el proceso cautelar y los derechos fundamentales en juego.

Optar por la aplicación de las reglas de la prueba indiciaria, además de coherente desde el punto de vista legal y carente de objeciones teóricas y jurídicas, permite establecer un marco que abre la puerta a la seguridad jurídica y que, desconocer o rechazar esta alternativa, niega. Cierto es que puede voluntaristamente ser rechazado porque, como se podrá inmediatamente comprender, sujetar la adopción de la prisión provisional a este complejo probatorio, conlleva derechamente la obligación inexcusable de respetar los principios en que se inspira y el respeto a los derechos fundamentales afectados. La prueba indiciaria asegura el cumplimiento de todos ellos y sujeta efectivamente a los tribunales a su respeto. Por eso, ni se invoca normalmente como mecanismo al que ha de someterse el acuerdo de la medida, que estrecha el margen de libertad judicial, excesivo en este ámbito cautelar, ni se admite, por cuanto, en realidad, más allá de las declaraciones ambiguas y genéricas que la jurisprudencia efectúa, la voluntad es la de permitir una cierta discrecionalidad que, aunque afecte a lo que se proclama, autoriza excepciones inquisitivas cuando así se desea. Particularismo que no siempre esconde intenciones que minan la independencia judicial y la vigencia del Estado de derecho.

Porque, cabe al menos plantearse la razón por la cual nunca la jurisprudencia ha destacado la necesidad de aplicar los mecanismos indiciarios en las operaciones de valoración de los riesgos cautelares, prefiriendo la inexplicable discrecionalidad imperante que promueve desigualdades e incertezas, pero que sirve, es evidente, para el cumplimiento de fines de naturaleza distinta a la cautelar. Porque ahí puede estar la razón: permitirse un amplio margen de libertad en la decisión que, solo acotada por criterios amplios, subjetivos, permite opciones alejadas de los fines estrictos de las medidas cautelares, pero adecuados a los llamados intereses generales o de grupo, cual sucede con ciertos delitos hoy determinantes de una criminalización social peligrosa por su orientación inquisitiva.

No existe ningún argumento jurídico que se oponga a que este mecanismo haya de utilizarse, pues se adapta perfectamente a las funciones de la prisión provisional y, a su vez, cierra la puerta a infracciones de los principios que la informan, de modo vinculante y a los derechos fundamentales de los que gozan los imputados. No existe, ni parece posible que se pueda argumentar 
en contrario. Lo que llama la atención es que nunca se haya planteado su articulación con rigor, que ni siquiera se haya aludido a su aceptación o rechazo.

No aceptar la plena aplicación de este mecanismo probatorio se traduce, como es sabido, en resoluciones y sentencias retóricas que dejan al arbitrio judicial la decisión de fondo y son estrictamente subjetivas y operan fuera del marco cautelar. Basta la simple convicción, el convencimiento íntimo, para justificar una medida de tal gravedad, que debe motivarse, pero cuya fundamentación es en muchos casos mera reiteración de la ley y de la creencia del juez.

Y así parece haberlo sostenido el TC peruano en el expediente 00192005-AI, de 21 de julio de $2005,{ }^{17}$ que manifiesta: "la detención preventiva es una medida cautelar limitativa del derecho fundamental a la libertad personal, válida en la medida de que se encuentre en riesgo el éxito del proceso penal, sea porque existe certeza o presunción fundada o razonable de que se pretende.....".

Someter esos acuerdos a las reglas de la prueba indiciaria supone supeditarlos a la verificación de condiciones estrictas en términos legales y constitucionales, a los requisitos que derivan del derecho a la presunción de inocencia cuando se trata de decretar una medida que anticipa una pena. No hacerlo equivale, como se ha dicho, a permitir un marco caracterizado por la ambigüedad y le retórica, pero abierto a la discrecionalidad y, en muchas ocasiones, a la arbitrariedad.

Un análisis de los elementos y requisitos de la prueba indiciaria, puestos en relación con los criterios que la ley establece en orden al acuerdo de la prisión provisional y los principios que la informan, así como los derechos fundamentales en juego, nos va a permitir acreditar la perfecta acomodación de este complejo probatorio a los análisis de procedencia de la prisión provisional y las condiciones a la que se somete.

\section{A. Indicios.}

La prueba indiciaria se basa en la presencia de indicios, siendo éstos de carácter objetivo, no equivalentes, pues, a sospechas o creencias. Los indicios son hechos indirectos, la base de la presunción. Los indicios, a pesar de la confusión reinante en la práctica judicial en la que el término

17 Citada por ORÉ GUARDIA, A. y LOZA AVALOS, G.: Las medidas cautelares personales en el proceso penal peruano. Editorial Reforma, Lima, 2011. Pág. 80. 
se usa para definir realidades y abstracciones, situaciones de hecho y estados de convencimiento, constituyen un concepto procesal indiscutible y elaborado, cuya alteración está en la raíz de tantos errores y desviaciones de las bases del proceso penal, desde su incoación, hasta su desarrollo y terminación.

Por ejemplo, es ordinario incoar un proceso, afirmando una imputación, cuando no se han definido objetivamente los elementos del tipo penal imputado, todos ellos, entendiendo suficientes las sospechas o previsiones subjetivas sobre la existencia de ciertos elementos del tipo inculpado. Se mezclan indicios y lucubraciones a las que se califica como indicios, generándose con ello el efecto de abrir procesos meramente prospectivos, investigaciones más policiales que procesales, que no procesos que implican una investigación. ${ }^{18}$

Por tanto, definir los indicios como hechos, como elementos objetivos, es imprescindible como punto de partida de este complejo probatorio en el que los subjetivo es determinante, pro en su lugar correspondiente y sobre la base de realidades.

Tales indicios, para servir de base a la presunción, han de estar necesariamente probados por medio de prueba directa, no pudiendo ser, a su vez, inferidos de otra presunción. Un indicio no puede ser acreditado mediante otro indicio en una cadena sin límites e incierta. La prueba ha de ser, pues, directa. Y la prueba es ineludible para que el indicio se constituye en base de la presunción.

Han de ser plurales. Es decir, no basta la presencia de un solo indicio para concluir la existencia del hecho presumido, dada la escasa fuerza de un solo elemento indirecto para llegar a una conclusión con la certeza necesaria. Podría bastar un indicio cuando su fuerza es determinante, pero lo ordinario es exigir la presencia de una pluralidad de hechos indirectos sobre los que construir la presunción y afirmar la culpabilidad y, en este caso, el peligro cautelar.

Esta pluralidad, que es consustancial a toda prueba indiciaria, se ve reflejada en la doctrina jurisprudencial dictada en materia de prisión provisional que, con carácter general, niega la posibilidad de que un solo motivo (indicio), sirva para concluir el riesgo de fuga de forma automática, siendo necesaria la coincidencia de una diversidad de indicios. En este

18 ASENCIO MELLADO, JM.: "La imputación como elemento determinante del modelo procesal de investigación”. En: Revista La Ley, 4 a 10 de enero de 2016. 
sentido, aunque con alguna excepción fruto de la discrecionalidad peligrosa en la que se mueve esta materia, excesivamente apegada a razones no jurídicas, la prisión provisional, al negar la suficiencia de un solo motivo, se pliega a las reglas de la prueba indiciaria cuya aplicación obligatoria permitiría negar legalmente la viabilidad de un solo motivo para el acuerdo salvo situaciones del todo punto excepcionales. En el caso de esta condición y aunque no se apliquen las normas de la prueba indiciaria, es cierto que la jurisprudencia impone este deber de presencia de más de un dato del que derivar el peligro, al menos el de fuga, pero también lo es que esta demanda queda reducida a mera formalidad cuando tales indicios se citan, se presentan, se exponen, sin que posteriormente se valoren en el marco del complejo probatorio en su conjunto y con arreglo a sus normas. Exigir una condición e ignorar las demás conduce a un resultado frustrante $y$, en muchas ocasiones, a meras resoluciones formales.

Además, de elementos objetivos, probados y plurales, los indicios han de ser concordantes y convergentes en un mismo resultado. $Y$ en materia de prisión provisional, todos los motivos argüidos han de concluir en el peligro que se afirma, de modo coherente y no contradictorio. Conducir a un resultado único, el riesgo que se asegura existir y que debe ser probado sin partir de presunción genérica alguna. Todos los indicios deben llevar a una misma conclusión, no a distintas posibilidades al mismo nivel de certeza o incerteza.

No han de concurrir, por tanto, en el caso contraindicios consistentes, siendo este dato de la prueba indiciaria, por otra parte, y de alguna forma presente en la jurisprudencia en materia de prisión provisional, esencial en orden a la adopción de la medida restrictiva de la libertad. Porque, si junto a los indicios que afirman el riesgo, aparecen otros que niegan dicho peligro, no se podrá afirmar la conclusión salvo que racionalmente no exista duda o no deba existir acerca de la fuerza real de los contraindicios. La presencia de indicios y de contraindicios, resta fuerza e impide la presunción si estos últimos son racionalmente sostenibles, de modo que la adopción de la prisión provisional quedaría sin sustento fáctico y sería solo expresión de una opción contraria a la excepcionalidad que obliga a decidir la libertad cuando su privación no esté plenamente acreditada.

Este dato es esencial. Si los contraindicios están acreditados plenamente, los indicios no pueden ser valorados más allá de su eventualidad hipotética, de modo que hacerlos valer de forma preferente es imposible en el marco de esta prueba indiciaria. Por ejemplo, si el imputado ha permanecido en 
libertad tras ser imputado o pendiente de serlo, no puede oponerse frente a esta realidad, frente a esa conducta contraria al indicio legalmente establecido, que cabe una posibilidad de fuga por razón de la gravedad de la pena o por poseer medios económicos suficientes. Los indicios, en este caso, estarían contradichos por los contraindicios, de modo que habría que probar algo más que una hipótesis, una nueva circunstancia que avalara la presunción contra la realidad contrastada. Las escasas referencias que se hacen a los hechos acreditados contrarios a los indicios que se usan para afirmar los riesgos son manifiestamente infracciones al complejo prueba indiciaria y abren la puerta a la pura y simple discrecionalidad, cuando no, arbitrariedad.

Frente a situaciones contradictorias operaría el derecho a la presunción de inocencia y la vigencia y preferencia de la libertad, fruto de la excepcionalidad, de modo que toda duda debe ser resuelta en favor de la vigencia del derecho, tanto a la libertad, como, si existen datos que avalen la necesidad y la proporcionalidad, la adopción de una medida menos intensa en cuanto a la restricción del mismo. El favor libertatis adquiere de este modo una consideración real, efectiva, no retórica e impide interpretaciones subjetivas, libérrimas y atentados al Estado de derecho. Y la duda, como se ha dicho y se insistirá en varias ocasiones no es, ni puede ser subjetiva, sino objetivada. No se trata de si existió duda en el Juez, sino si debió existir sobre la base de los indicios presentes en el caso (STS español de 17 de marzo de 2015).

\section{B. El razonamiento deductivo.}

La prueba indiciaria exige un razonamiento que es expresión de la exigencia de indicios probados y concordantes en un resultado determinado, el riesgo cautelar en este ámbito que se trata.

El TS español, en su sentencia de fecha 27 de febrero de 2012, resume perfectamente qué se debe entender por inferencia lógica, racional y coherente con los requisitos de la prueba indiciaria, sentencia ésta que puede ser asumida sin mayores reparos al momento del acuerdo de la prisión provisional, medida anticipatoria de la pena y restrictiva de la libertad de quien no ha sido declarado culpable.

“A) Con carácter general, el contenido constitucional del derecho a la presunción de inocencia implica: 
a) Que la aceptación convencida por el Juzgador de la verdad de la imputación se haya atenido al método legalmente establecido lo que ocurría si los medios de prueba sean considerados válidos y el debate se someta a las condiciones de contradicción y publicidad.

b) Que, en relación al resultado de la actividad probatoria, la certeza del Juzgador pueda asumirse objetivamente y no como mero convencimiento subjetivo de aquél. Tal objetividad no exige que las conclusiones sean absolutamente incuestionables, pero si que resulten fundadas por su vinculación a la actividad probatoria. Lo que ocurrirá si, a su vez: $1^{\circ}$ ).- puede afirmarse la inexistencia de vacio probatorio, porque los medios de prueba practicados hayan aportado un contenido incriminador y $2^{\circ}$ ).- la revisión de la valoración hecha por el juzgador de instancia de tales medios y contenidos permita predicar de la acusación una veracidad objetivamente aceptable, $y$, en igual medida, estimar excluible su mendacidad. Ocurrirá así cuando se justifique esa conclusión por adecuación al canon de coherencia lógica, partiendo de proposiciones tenidas indiscutidamente por correctas.

c) Y eso en relación a los elementos esenciales del delito, tanto objetivos como subjetivos, y, entre ellos, a la participación del acusado.

d) Finalmente, la objetiva razonabilidad de la aceptación de la acusación requiere la inexistencia de alternativas razonables a la hipótesis que justificó la condena. Y ello porque, para establecer la satisfacción del canon de razonabilidad de la imputación, además, se requiere que las objeciones oponibles se muestren ya carentes de motivos racionales que las justifiquen de modo tal que pueda decirse que excluye, para la generalidad, dudas que puedan considerarse razonables. Bastará, eso sí, que tal justificación de la duda se consiga, o, lo que es lo mismo, que existan buenas razones que obsten aquella certeza objetiva sobre la culpabilidad, para que la garantía constitucional deje sin legitimidad una decisión de condena. Sin necesidad, para la consiguiente absolución, de que, más allá, se justifique la falsedad de la imputación. Ni siquiera la mayor probabilidad de esa falsedad.

Puede pues decirse, finalmente, que cuando existe una duda objetiva debe actuarse el efecto garantista de la presunción constitucional, con la subsiguiente absolución del acusado.

Sin que aquella duda sea parangonable a la duda subjetiva del juzgador, que puede asaltarle pese al colmado probatorio que justificaría la condena. Esta duda también debe acarrear la absolución, pero fuera ya 
del marco normativo de exigencias contenidas en el derecho fundamental a la presunción de inocencia".

La aplicación de las normas que esta sentencia establece para la prueba indiciaria, adaptadas a la prisión provisional, ofrece un marco de seguridad que impide la plena libertad que se produce con relativa frecuencia y obliga a una motivación real, una motivación que impida decisiones arbitrarias o inmotivadas y que en esta resolución se afirma que deberían ser perseguidas disciplinariamente por su gravedad y afectación a los derechos fundamentales.

-La decisión derivada de la inferencia debe expresar una certeza que se pueda asumir objetivamente, pues no basta el mero convencimiento judicial contra los hechos y datos, como manifestación de la creencia interna y la resolución tal vez previa. Como afirma el TS español en su sentencia de fecha 17 de abril de 2015, cuando se entra en el terreno de la cadena lógica, nos adentramos en el de la incertidumbre; de ahí la necesidad de un plus argumentativo, de una motivación especial y sujeta a condiciones.

" $Y$ como quiera que cuando se pone en marcha la cadena lógica, nos adentramos en el terreno de las incertidumbres, la necesidad de un plus argumentativo sejustifica por si sola. El juicio histórico y la fundamentación jurídica han de expresar, con reforzada técnica narrativa, la hilazón lógica de los indicios sobre los que se construye la condena. El proceso deductivo ha de quedar plasmado en toda su extensión, permitiendo así un control de la racionalidad del hilo discursivo mediante el que el órgano jurisdiccional afirma la condena. Ha de quedar al descubierto el juicio de inferencia como actividad intelectual que sirve de enlace a un hecho acreditado y su consecuencia lógica (cfr. SSTS 587/2014, 18 de julio; 947/2007, 12 de noviembre y STS 456/2008, 8 de julio, entre otras)'”.

En materia de prisión provisional se requiere, igualmente, la certeza judicial acerca de los riesgos que se afirman, no bastando su mera probabilidad. Y ello es así porque la duda debe resolverse en favor de la libertad en aplicación del principio de excepcionalidad que alcanza, de este modo, una efectiva consideración. No basta, pues, la mera posibilidad del riesgo, su eventualidad, sino el convencimiento objetivo de su verificación. De no aceptarse esta regla, es claro que la excepcionalidad cedería en favor de la regla contraria.

Una cosa, que hay que distinguir necesariamente, es el grado de convencimiento acerca de la comisión del delito, que, por estar el proceso en sus comienzos no puede equipararse a la certeza propia de la sentencia, 
bastando, pues, una probabilidad elevada; pero, otra, no equiparable es el que se demanda para valorar los riesgos, en tanto éstos son presentes, no futuros, no evaluables en la sentencia e independientes del fondo del asunto hasta su conclusión. La prueba de los mismos es la que se presenta en el momento de su aceptación y el estado de cosas, el que se verifica cuando ha de acordarse la medida cautelar.

Las referencias que se hacen a estos términos que se vinculan al convencimiento son, evidentemente, relativas, de modo que no es su entendimiento subjetivo lo que se quiere destacar y a lo que ha de atenderse, sino a una certeza medida objetivamente, única forma procesal de controlar las decisiones judiciales. Cuando se habla, pues, de certeza se hace refiriendo ésta a los datos objetivos en que se apoye la resolución y los que se opongan a la misma, con especial atención a la razonabilidad o fuerza de estos últimos para oponerse a las conclusiones afirmadas. Certeza objetiva que obliga, como ya se ha dicho, a dudar a los tribunales aunque no tengan esa duda en su fuero interno. La convicción por sí misma no constituye razón suficiente en un Estado de derecho si no se apoya en elementos que la conforman.

-La motivación se ha de hacer desde una reforzada técnica. Se ha de expresar la ilación lógica existente entre los indicios y el proceso deductivo, para así poder asegurarse el control de ese proceso, su racionalidad.

En este sentido, se ha de expresar el riesgo concreto que se quiere prevenir, exactamente y su relación con los indicios, sin que baste una simple referencia a los indicios sin vincularlos en el caso con el peligro concreto que se afirma. No basta, pues, aludir a un riesgo genérico que se presume desde la consideración de un indicio también general y abstracto. Esto no es motivación suficiente. No es admisible una presunción legal, de cualquier signo, sino una presunción judicial que sea consecuencia de una valoración y acreditación racional y objetiva.

Como ya se ha dicho, la ausencia de una motivación suficiente o su sustitución por una formal o aparente, equivale a una infracción de los derechos a la libertad y a la presunción de inocencia sin más consideraciones.

-La certeza de la decisión se mide por su razonabilidad, por la inexistencia en el caso de alternativas razonables. Así lo afirma el art. 158,3 NCPP al considerar como elemento que impide la inferencia presuntiva la existencia en el caso de contraindicios consistentes. 
No se trata, evidentemente, de que las conclusiones sean absolutamente incuestionables, pero sí de que no haya en el caso alternativas razonables que las desmientan o las hagan perder valor y eficacia al minar la certeza exigible.

Este es el elemento esencial en orden a la objetivación de la prueba indiciaria y fácilmente evaluable y controlable. Porque, sin duda, es difícil controlar la racionalidad de una decisión en sí misma considerada. Pero, por el contrario, es posible y accesible hacerlo tomando como referencia las alternativas razonables a la conclusión judicial, no las meras eventualidades, sino las posibles consecuencias distintas y derivadas de la cadena y pluralidad de indicios. Alternativas que alcanzan mayor fuerza cuando se basan en conductas contrastadas, frente a meras lucubraciones intelectuales sobre riesgos teóricos cuya base se limita a coincidir con un peligro legalmente destacado.

-Y, en suma, la duda, la duda objetiva derivada de la concurrencia de indicios y contraindicios razonables, no la subjetiva, debe resolverse siempre a favor del imputado y su libertad. La existencia de contraindicios consistentes y razonables debe conducir a la libertad y, si la duda versa sobre la eficacia de las medidas alternativas, hacerse a favor de estas últimas.

\section{Bibliografía}

ASENCIO GALLEGO, JM.: "Presunción de inocencia y presunciones iuris tantum en el proceso penal". En: Revista General de Derecho Procesal. $\mathrm{N}^{\mathrm{o}} 36,2015$.

ASENCIO MELLADO, JM.: La prisión provisional. Civitas, Madrid, 1987.

ASENCIO MELLADO, JM: Prueba prohibida y prueba preconstituida. S.A. Trivium, Madrid 1989.

ASENCIO MELLADO, JM.: "Presunción de inocencia y prueba indiciaria". En: Cuadernos de Derecho Judicial. Madrid, 1992.

ASENCIO MELLADO, JM.: "La imputación como elemento determinante del modelo procesal de investigación". En: Revista La Ley, 4 a 10 de enero de 2016. 
ASENCIO MELLADO, JM.: "La objetivación de los criterios para la apreciación del fumus boni iuris y el periculum in mora en la prisión provisional". En: Derecho y proceso. Libetr amicorum del profesor Francisco Ramos Méndez. Atelier, Barcelona 2018.

BARONA VILAR, S.: Seminario obre detención y prisión provisional (Obra colectiva). Santiago de Compostela. 1995.

CALVO SÁNCHEZ, C: "De nuevo sobre la prisión provisional. Análisis de la Ley Orgánica 10/1984, de 26 de diciembre”. En: Revista La Ley, 22 de marzo de 1985.

CASTILLO ALVA, JL.: La presunción de inocencia como regla de tratamiento. Vol. I. Ideas Solución Editorial S.A.C., Lima 2018.

DEL RÍO LABARTHE, G: Las medidas cautelares personales del proceso penal peruano. Tesis Doctoral. Universidad de Alicante. 2009.

FERNÁNDEZ LÓPEZ, M.: Prueba y presunción de inocencia. Iustel, Madrid 2005.

GARCÍA CAVERO, P.: La prueba por indicios en el proceso penal. Editorial Reforma S.A.C., Lima 2010.

MATTES, H.: "La prisión preventiva en España”. En: Anuario de Derecho Penal y Ciencias Penales, fascículo 2, Madrid, 1975.

ORÉ GUARDIA, A. y LOZA AVALOS, G.: Las medidas cautelares personales en el proceso penal peruano. Editorial Reforma, Lima, 2011.

ORTELLS RAMOS, M: "Para una sistematización de las medidas cautelares”. En: RGLJ., Mayo, 1978.

ORTELLS RAMOS, M. y TAPIA FERNÁNDEZ, I.: El proceso penal en la doctrina del Tribunal Constitucional (1981-2004). Thomson Aranzadi, Navarra 2005.

PRIETO-CASTRO, L.: Tratado de Derecho Procesal Civil. Aranzadi, Navarra 1985.

PRIORI, G.: "El procedimiento preestablecido en la ley: la crisis de una garantía procesal y su rediseño en el Estado constitucional". En Proceso y Constitución. Las garantías del justo proceso. Palestra Editores, Lima, 2013. 
SAN MARTÍN CASTRO, C: Derecho Procesal Penal. Lecciones. INPECCP- CENALES, Lima, 2015.

SERRA DOMÍNGUEZ, M.: "Función del indicio en el proceso penal". En: Estudios de Derecho Procesal. Librería Bosch, Barcelona 1969.

SERRA DOMÍNGUEZ, M: Seminario sobre detención y prisión provisional. Santiago de Compostela. 1995.

SUMARIA BENAVENTE, O: "El antiformalismo como presupuesto teórico para una tutela jurisdiccional efectiva". En: Revista Jurídica Thomson Reuters, №35.

TORRES-DULCE LIFANTE, E.: "Seminario sobre detención y prisión provisional". Santiago de Compostela. 1995. 